\title{
持続的血液透析中にtorsades de pointesを生じたフッ化水 素中毒の1例
}

\begin{tabular}{|c|c|c|c|c|}
\hline 亭* 1 & 渡邊 & 善寛*1 & 吉岡 早戸*1 & 長谷川栄寿*1 \\
\hline 義座*1 & 加藤 & 宏*1 & 小井土雄一* 1 & 正人 $* 2$ \\
\hline
\end{tabular}

\begin{abstract}
要約：症例は39歳の男性。塗装作業中にタイル洗浄用クリーナー（フッ化水素酸 $1.3 \%$, フッ 化アンモニウム $10 \%$ を含有) を誤飲し, 当院へ救急搬送された。胃管より牛乳を投与した後, ICUに入室した。フッ化水素中毒による低Ca 血症に対しては, グルコン酸カルシウムを静脈 投与した。また来院 4 時間後頃より血清 $\mathrm{K}$ 濃度が急激に上昇したため, continuous hemodialysis (CHD) を施行した。来院7時間後にtorsades de pointes (TdP) が生じたが, 硫酸マグ ネシウム $2 \mathrm{~g}$ を投与したところ，洞調律に回復した。TdPが生じた時の血清 $\mathrm{Mg}$ 濃度は 0.8 $\mathrm{mg} \cdot \mathrm{d} l^{-1}$ と著明な低值であり，これが $\mathrm{TdP}$ の原因の 1 つ考えられた。これは，透析液中の $\mathrm{Mg}$ 濃度が $1.2 \mathrm{mg} \cdot \mathrm{d} l^{-1}$ と, 慢性腎不全患者を対象として低值に設定されているために, フッ 化水素中毒による低 $\mathrm{Mg}$ 血症に加えて, CHDによりさらに低 $\mathrm{Mg}$ 血症が悪化した可能性が考え られた。
\end{abstract}

Key words: (1) torsades de pointes (TdP), (2) hydrogen fluoride poisoning, (3) continuous hemodialysis (CHD)

\section{はじめに}

フッ化水素剂を多量に服用すると, 低 Ca 血症・高 $\mathrm{K}$ 血症と共に低 $\mathrm{Mg}$ 血症を生じることが知られてい る。心室細動や重篤な心筋障害をきたした急性期報告 例は散見されるが, 我々は, フッ化水素中毒による 高 $\mathrm{K}$ 血症に対して持続的血液透析 (continuous hemodialysis, CHD) を施行中に, 低 Mg 血症が原因の 1つと考えられるtorsades de pointes (TdP) を生じた 症例を経験した。CHD施行中は，理論的には血清電 解質濃度は透析液と平衡を保つようになることから, 透析液中の $\mathrm{Mg}$ 濃度に対する考察を含め, 教訓的意義 を踏まえて報告する。

\section{症 例}

患者 : 39歳の男性。

主訴：嘔気, 嘔吐, 口腔内の疼痛。

既往歴：特記事項なし。

現病歴：塗装作業中にジュース缶に分けておいた タイル洗浄用クリーナー (ミカゲクリーナー ${ }^{\circledR}$; フッ
化水素酸 $1.3 \%$, フッ化アンモニウム $10 \%$ を含有)を誤 飲し, 当院へ救急搬送された。救急搬送中に救急車内 で3回嘔吐した。正確な摂取量は不明であった。

来院時現症：意識レベルGlasgow coma scale (GCS) E3V5M6, 呼吸数 $26 \mathrm{~min}^{-1}$, 心拍数 $109 \mathrm{~min}^{-1}$, 血圧 $140 / 67 \mathrm{mmHg}$, 体温 $34.9^{\circ} \mathrm{C}$ であった。顔面は蒼 白で, 流涎が多量であった。口腔内には淡褐色の吐物 があり, 四肢に知覚障害を認めた。水様性の便失禁を 認めた。

来院時検査所見 (Table 1) : AST $48 \mathrm{IU} \cdot l^{-1}$, ALT $46 \mathrm{IU} \cdot l^{-1}$ と軽度のトランスアミナーゼの上昇を認 めたほか, Ca $4.5 \mathrm{mg} \cdot \mathrm{d} l^{-1}$ と低Ca血症を認めた。

尿中薬物定性反応：全て陰性。

胸部 X 線所見：心拡大なし。

十二誘導心電図所見：QRS 間隔93 msec, QTc(補 正QT間隔) $493 \mathrm{msec}^{\circ}$

入院後経過：誤飲から約 30 分後に当院へ救急搬送 された。静脈路を確保した後, 消化管粘膜の状態を確 認するために上部消化管内視鏡を施行し, 上部食道か ら十二指腸に至るまで多発性のびらん面および出血を

\footnotetext{
*1独立行政法人国立病院機構災害医療センター救命救急センター

（テ190-0014 東京都立川市緑町 3256）

*2 鳥取大学医学部救急災害医学分野 (T 683-8503 鳥取県米子市西町 86)
} 
日集中医誌 J Jpn Soc Intensive Care Med Vol. 17 No. 3

Table 1 Laboratory data on admission

\begin{tabular}{|c|c|c|c|}
\hline Blood cell count & & $\mathrm{Na}$ & $138 \mathrm{mEq} \cdot l^{-1}$ \\
\hline WBC & $6,400 \mu l^{-1}$ & $\mathrm{~K}$ & $3.7(3.6 \sim 4.9) \mathrm{mEq} \cdot l^{-1}$ \\
\hline $\mathrm{RBC}$ & $540 \times 10^{4} \mu l^{-1}$ & $\mathrm{Cl}$ & $97 \mathrm{mEq} \cdot l^{-1}$ \\
\hline $\mathrm{Hb}$ & $16.9 \mathrm{~g} \cdot \mathrm{d} l^{-1}$ & $\mathrm{Ca}$ & $4.5(8.7 \sim 10.3) \quad \mathrm{mg} \cdot \mathrm{d} l^{-1}$ \\
\hline $\mathrm{Ht}$ & $49.1 \%$ & CRP & $0.1 \mathrm{mg} \cdot \mathrm{d} l^{-1}$ \\
\hline Plt & $18.9 \times 10^{4} \mu l^{-1}$ & GLU & $272 \mathrm{mg} \cdot \mathrm{d} l^{-1}$ \\
\hline Biochemistory & \multicolumn{3}{|c|}{ Coagulation system } \\
\hline $\mathrm{TP}$ & $7.9 \mathrm{~g} \cdot \mathrm{d} l^{-1}$ & APTT & $20.7 \mathrm{sec}$ \\
\hline TB & $1.0 \mathrm{mg} \cdot \mathrm{d} l^{-1}$ & PT & $87 \%$ \\
\hline UN & $14.4 \mathrm{mg} \cdot \mathrm{d} l^{-1}$ & \multicolumn{2}{|c|}{ Blood gas analysis } \\
\hline $\mathrm{Cr}$ & $1.58 \mathrm{mg} \cdot \mathrm{d} l^{-1}$ & \multicolumn{2}{|c|}{$6 l \cdot \min ^{-1}$ nonbreather mask } \\
\hline AST & $48 \mathrm{IU} \cdot l^{-1}$ & $\mathrm{pH}$ & 7.279 \\
\hline ALT & $46 \mathrm{IU} \cdot l^{-1}$ & $\mathrm{PaCO}_{2}$ & $24.2 \mathrm{mmHg}$ \\
\hline $\mathrm{LDH}$ & $322 \mathrm{IU} \cdot l^{-1}$ & $\mathrm{PaO}_{2}$ & $135.7 \mathrm{mmHg}$ \\
\hline AMY & $244 \mathrm{IU} \cdot l^{-1}$ & $\mathrm{HCO}_{3}{ }^{-1}$ & $11.1 \mathrm{mmol} \cdot l^{-1}$ \\
\hline $\mathrm{CPK}$ & $139 \mathrm{IU} \cdot l^{-1}$ & $\mathrm{BE}$ & $-13.1 \mathrm{mmol} \cdot l^{-1}$ \\
\hline
\end{tabular}

Normal values are given in parentheses.

AMY, amylase; APTT, activated partial thromboplastin time; $\mathrm{Ca}$, calcium; $\mathrm{Cl}$, chloride; $\mathrm{Cr}$, creatinine; GLU, glucose; K, potassium; Na, sodium; Plt, platelet; PT, prothrombin time; TB, total bilirubin; TP, total protein; UN, urea nitrogen.

認めた。胃管を留置して牛乳を投与し, 経過観察目的 でICUに入室となった。来院約 1 時間後に血圧が低下 し, 循環動態が不安定になったため, 経口気管挿管し, 人工呼吸管理とした。

低 Ca 血症に対して, 誤飲後推定 5 時間までにグルコ ン酸カルシウム $850 \mathrm{mg}$ を合計 9 回 (Ca 7,650 mg) 静 脈投与し, その後グルコン酸カルシウムの持続投与 $\left(\mathrm{Ca} 850 \mathrm{mg} \cdot \mathrm{hr}^{-1}\right)$ を開始した。

来院 4 時間後頃から血清 $\mathrm{K}$ 濃度が急激に上昇し始 め, $3.70 \mathrm{mEq} \cdot l^{-1}$ から $6.05 \mathrm{mEq} \cdot l^{-1}$ にまで到達し たため, CHDを開始した。

ヘモフィルターは polyacrylonitrile (PAN) 膜 (膜面 積 $\left.0.7 \mathrm{~m}^{2}\right)$ を使用し, 血液流量は $80 \mathrm{~m} l \cdot \mathrm{min}^{-1}$, 透析 液はサブラッド $\mathrm{BS}^{\circledR}$ (扶桑薬品)を使用し, 透析液流量 は $14 \mathrm{ml} \cdot \mathrm{min}^{-1}$ とした。抗凝固薬はメシル酸ナファ モスタットを使用した。

来院 7 時間後に数回の TdPが出現し (Fig. 1), 硫酸 マグネシウム $2 \mathrm{~g}$ を投与したところ, 洞調律に回復し た。第 1 病日, 特に来院 9 時間後までの経過を Fig. 2 に 示した。

その後の経過は, 心室性期外収縮が散発したものの, リドカインの持続投与を行い循環動態は安定した。な お, CHDはTdP発生 3 時間後に終了した。第 4 病日に は血小板数が $3.4 \times 10^{4} \mu l^{-1}$ まで減少して播種性 血管内凝固症候群 (disseminated intravascular coagulopathy, DIC) を併発したが, メシル酸ガベキ
サートを投与し，第 7 病日には $13.0 \times 10^{4} \mu l^{-1}$ にまで 改善した。同日抜管し, 第 12 病日には独歩退院した。

\section{考察}

フッ化水素は無色の気体または液体であるが, 大気 中の水分と反応してフッ化水素酸となる ${ }^{1)} 。 フ ッ$ 化水 素酸はガラス腐食剤, フッ素樹脂などの中間材料, 石 油化学におけるアルキル化剤として広く用いられてい る2)。このフッ化水素酸は皮膚や粘膜に極めて強い刺 激性と腐食性をきたすことでよく知られている1)。多 くの場合は皮膚より吸収されて傷害をきたすが, 肺や, 本症例のように消化管からも容易に吸収される。吸収 されてイオン化したフッ素イオンは, 血流を通して速 やかに全身に分布し, 肺, 肝臓, 腎臓そして骨に高濃 度に集積する ${ }^{3), 4) 。 ~}$

フッ化水素の作用は, 局所での腐食作用, 陽イオン との結合による電解質異常, 酵素の阻害による代謝障 害がある。経口摂取した場合, 消化管粘膜の傷害, 血 中 $\mathrm{Ca} \cdot \mathrm{Mg}$ との結合による低 $\mathrm{Ca}$ ・低 $\mathrm{Mg}$ 血症, 細胞膜 の $\mathrm{Na}^{+}, \mathrm{K}^{+}$-ATPase (adenosine triphosphatase) 酵 素の障害による高 $\mathrm{K}$ 血症を引き起こし, 致死性不整脈 が生じると考えられる5) 7)。

フッ化水素を含んだ液体を服用した場合には, 緊急 処置が必要である。理論的には, 牛乳を経口投与する ことによりフッ化水素の吸収を遅らせることができる が, 腐食性の強い液体のため, 消化器症状が強い場合 


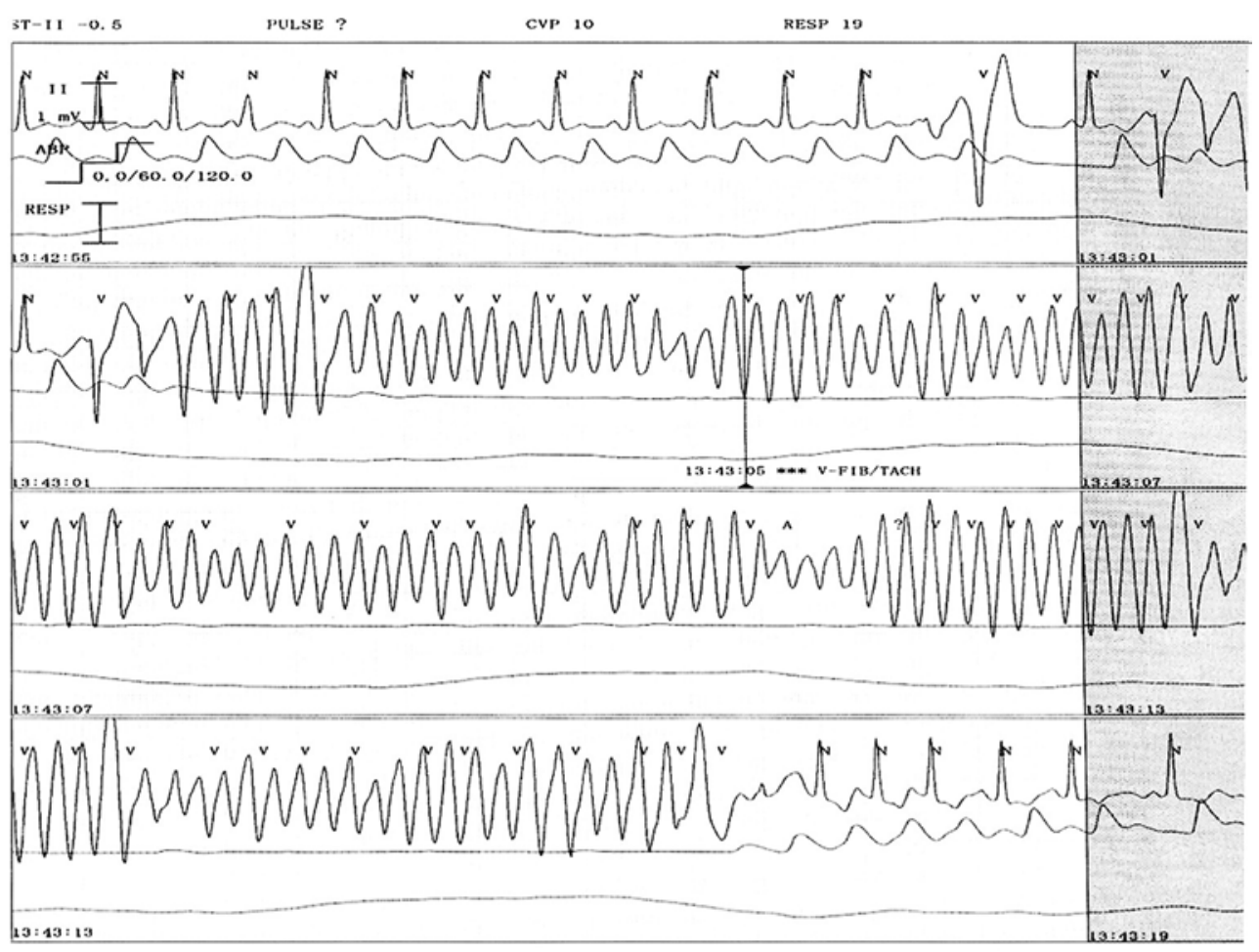

Fig. 1 The electrocardiogram monitored in the ICU

The electrocardiogram showed torsades de pointes followed by sinus rhythm.

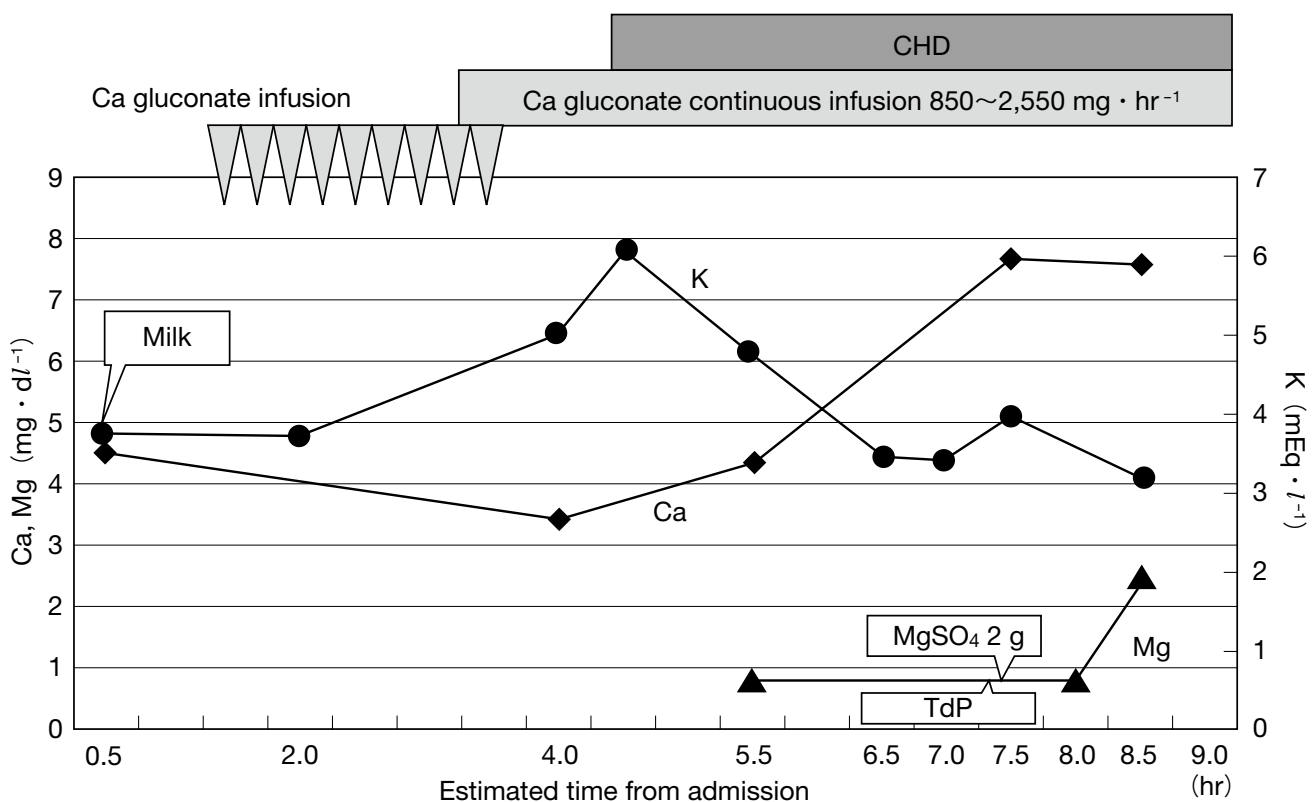

Fig. 2 Clinical course and treatment of the patient on the first day of the admission Milk was administered via nasogastric tube. TdP developed suddenly 7 hrs after his admission to the hospital. $2 \mathrm{~g}$ of $\mathrm{MgSO}_{4}$ was administered immediately and the cardiac rhythm was restored. At the time of TdP, his blood K level was found to be $3.97 \mathrm{mEq} \cdot l^{-1}$. During CHD and after Ca administration, his blood Ca level was found to be $7.68 \mathrm{mg} \cdot$ $\mathrm{d} l^{-1}$. However, the $\mathrm{Mg}$ level was as low as $0.8 \mathrm{mg} \cdot \mathrm{d} l^{-1}$.

$\mathrm{CHD}$, continuous hemodialysis; $\mathrm{MgSO}_{4}$, magnesium sulfate; $\mathrm{TdP}$, torsades de pointes. 
には投与できない。重症例では胃穿孔の報告もある8)。 また低 $\mathrm{Ca}$ ・低 $\mathrm{Mg}$ 血症に対しては, 積極的な $\mathrm{Ca}, \mathrm{Mg}$ の投与が必要となる9)。本症例においては, 低Ca血 症に対して $\mathrm{Ca}$ 製剂を静脈投与したが， $\mathrm{TdP}$ 出現以前 は Mgを投与していなかったことは反省点として挙げ られる。

血液透析に関しては, 低 $\mathrm{Ca} ・$ 高 $\mathrm{K}$ 血症の補正が可 能であるほか, 血中フッ化水素自体の除去が可能との 報告もある10),11)。本症例での血清 $\mathrm{K}$, 血清 $\mathrm{Ca}$, 血清 $\mathrm{Mg}$ 濃度の入院後経過中の極值はそれぞれ K 6.05 $\mathrm{mEq} \cdot l^{-1}$, Ca $3.4 \mathrm{mg} \cdot \mathrm{d} l^{-1}, \mathrm{Mg} 0.8 \mathrm{mg} \cdot \mathrm{d} l^{-1}$ で あった。入院後の治療により $\mathrm{TdP}$ 発生時は Kが 3.97 $\mathrm{mEq} \cdot l^{-1}$, Caが $7.68 \mathrm{mg} \cdot \mathrm{d} l^{-1}$ と基準值近くまで補 正されていたが, $\mathrm{Mg}$ は $0.8 \mathrm{mg} \cdot \mathrm{d} l^{-1}$ と著明に低值で ありここれが TdPの原因の1つであったと考えられる。

CHD施行中は, 理論的には血清電解質濃度は透析 液と平衡を保つようになることから，透析液（サブ ラット $\left.\mathrm{BS}^{\circledR}\right)$ は慢性腎不全に扔ける高 $\mathrm{Mg}$ 血症に対処 するため $\mathrm{Mg}$ 濃度は $1.2 \mathrm{mg} \cdot \mathrm{d} l^{-1}$ と低值に設定され て抢り,フッ化水素中毒に扔ける低 $\mathrm{Mg}$ 血症の補正に は不十分であったと考えられる。

また, フッ化水素は心筋細胞の Naチャネルを直接 阻害し, 脱分極を遅延させてQRS幅を拡大させるほ か, 活動電位第3期においてK流出チャネルを阻害す ることにより，QT 間隔を延長させることが報告され ている ${ }^{12)}$ 。TdPの原因としては, 一般的に薬剂, 低 $\mathrm{Ca}$ 血症・低 $\mathrm{Mg}$ 血症などの電解質異常が考えられる が, 本症例で $\mathrm{TdP}$ が発生した原因としては, 低 $\mathrm{Mg}$ 血 症に加え，心筋への直接的な障害があったと考えられ た。TdP発生時に硫酸マグネシウム $2 \mathrm{~g}$ を投与し, 洞 調律に回復した約 3 時間後にCHDを終了したことは, 結果的に低 $\mathrm{Mg}$ 血症を悪化させなかった要因であっ た。

フッ化水素酸の飲用による中毒の場合, 生命予後は 不良であり，多くの場合は低Ca血症により飲用後3〜 6 時間後に死亡している8),13)。しかし, 本症例では $\mathrm{TdP}$ 生じたものの, 来院当初からの速やかな低 $\mathrm{Ca}$ 血症・高 $\mathrm{K}$ 血症に対する電解質補正と, $\mathrm{TdP}$ 発生後で
はあるが，Mgを投与したことにより，独歩退院する ことができたと考える。

\section{結 語}

フッ化水素中毒による高 $\mathrm{K}$ 血症・低Ca 血症に対し て血液透析を施行した場合, 透析液中の $\mathrm{Mg}$ 濃度は低 く設定されており，低 $\mathrm{Mg}$ 血症は透析によって補正さ れないため, $\mathrm{K}, \mathrm{Ca}$ だけではなく $\mathrm{Mg}$ にも十分注意し なければならない。さらに, フッ化水素そのものによ る心筋への影響も考慮されるため, TdPを含めた不整 脈には十分な注意が必要である。

本稿の要旨は, 第 35 回日本集中治療医学会学術集会 $(2008$ 年, 東京)において発表した。

\section{文 献}

1) 井上尚英, 林田嘉郎. 職業関連性疾患 フッ化水素中毒. 産業医ジャーナル 1993;14:32-7.

2) 吉田康久, 渡辺美鈴, 河野公一. フッ化水素酸の経皮吸収 と臓器中フッ化物濃度について。産業医 1975;17:281-7.

3) 井上尚英, 槇田裕之. フッ化水素中毒の治療. 臨と研 1995;72:132-5.

4) 若杉長英, 増井美保, 濱口充代, 他. 急性フッ化水素中毒 の1剖検例. 救急医学 1987;11:113-5.

5) McIvor ME. Delayed fatal hyperkalemia in a patient with acute fluoride intoxication. Ann Emerg Med 1987;16: 1165-7.

6) Abkurah AR, Moser AM Jr, Baird CL, et al. Acute sodium fluoride poisoning. JAMA 1972;222:816-7.

7) Klasner AE, Scalzo AJ, Blume C, et al. Marked hypocalcemia and ventricular fibrillation in two pediatric patients exposed to a fluoride-containing wheel cleaner. Ann Emerg Med 1996;28:713-8.

8) Menchel SA, Dunn WA. Hydrofluoric acid poisoning. Am J Forensic Med Pathol 1984;5:245-8.

9) Stremski ES, Grande GA, Ling LJ. Survival following hydrofluoric acid ingestion. Ann Emerg Med 1992;21: 1396-9.

10) McIvor ME, Cummings CE, Mower MM, et al. Sudden cardiac death from acute fluoride intoxication: the role of potassium. Ann Emerg Med 1987;16:777-81.

11) Yolken R, Konecy P, McCarthy P. Acute fluoride poisoning. Pediatrics 1976;58:90-3.

12) Holstege C, Baer A, Brady WJ. The electrocardiographic toxidrome: the ECG presentation of hydrofluoric acid ingestion. Am J Emerg Med 2005;23:171-6.

13) 佐藤重仁, Braud F, Bismuth C, 他. フッ化水素酸, シュ ウ酸による中毒. 救急医学 1985;9:1821-4. 


\section{Abstract \\ A case of torsades de pointes on continuous hemodialysis in a patient with acute fluoride intoxication}

Toru Hifumi*1, Yoshihiro Watanabe*1, Hayato Yoshioka*1, Eiju Hasegawa*1, Yoshikura Haraguchi*1, Hiroshi Kato*1, Yuichi Koido*1, Masato Homma*2

${ }^{* 1}$ Division of Critical Care Medicine and Trauma, National Hospital Organization Disaster Medical Center

${ }^{*}$ Division of Emergency and Disaster Medicine, Tottori University Faculty of Medicine

*1 3256 Midoricho, Tachikawa, Tokyo 190-0014, Japan

*2 86 Nishimachi, Yonago, Tottori 683-8503, Japan

A 39-year-old man accidentally ingested a cleaning solution containing $1.3 \%$ hydrofluoric acid and 10\% ammonium fluoride. He was brought to our hospital within half an hour of this episode. He was fed milk via a nasogastric tube and admitted to the ICU. As a treatment for prolonged hypocalcemia, calcium gluconate was administered. Continuous hemodialysis (CHD) was performed because of rapidly progressive hyperkalemia. Within 4 hrs of hospitalization, his blood potassium level increased rapidly. Torsades de pointes (TdP) developed suddenly $7 \mathrm{hrs}$ after his admission to the hospital; $2 \mathrm{~g}$ of magnesium sulfate was administered immediately and the cardiac rhythm was restored. At the time of TdP, his blood $\mathrm{K}$ level was found to be $3.97 \mathrm{mEq} \cdot l^{-1}$. During $\mathrm{CHD}$ and after Ca administration, his blood Ca level was found to be $7.68 \mathrm{mg} \cdot \mathrm{d} l^{-1}$. However, the $\mathrm{Mg}$ level was as low as $0.8 \mathrm{mg} \cdot \mathrm{d} l^{-1}$, and this was suspected to be the cause of TdP. The $\mathrm{Mg}$ concentration of the fluid used for CHD has been adjusted to $1.2 \mathrm{mg} \cdot \mathrm{d} l^{-1}$, which is the concentration used for patients with chronic renal failure. Therefore, this concentration was not appropriate for our patient with hypomagnesemia.

Key words: (1) torsades de pointes (TdP), (2) hydrogen fluoride poisoning, (3) continuous hemodialysis (CHD)

J Jpn Soc Intensive Care Med 2010;17:321 325. 